\title{
Diet and nonalcoholic fatty liver disease
}

Citation for published version (APA):

Mensink, R. P., Plat, J., \& Schrauwen, P. (2008). Diet and nonalcoholic fatty liver disease. Current Opinion in Lipidology, 19(1), 25-29. https://doi.org/10.1097/MOL.0b013e3282f382ea

Document status and date:

Published: 01/01/2008

DOI:

10.1097/MOL.0b013e3282f382ea

Document Version:

Publisher's PDF, also known as Version of record

Document license:

Taverne

Please check the document version of this publication:

- A submitted manuscript is the version of the article upon submission and before peer-review. There can be important differences between the submitted version and the official published version of record.

People interested in the research are advised to contact the author for the final version of the publication, or visit the DOI to the publisher's website.

- The final author version and the galley proof are versions of the publication after peer review.

- The final published version features the final layout of the paper including the volume, issue and page numbers.

Link to publication

\footnotetext{
General rights rights.

- You may freely distribute the URL identifying the publication in the public portal. please follow below link for the End User Agreement:

www.umlib.nl/taverne-license

Take down policy

If you believe that this document breaches copyright please contact us at:

repository@maastrichtuniversity.nl

providing details and we will investigate your claim.
}

Copyright and moral rights for the publications made accessible in the public portal are retained by the authors and/or other copyright owners and it is a condition of accessing publications that users recognise and abide by the legal requirements associated with these

- Users may download and print one copy of any publication from the public portal for the purpose of private study or research.

- You may not further distribute the material or use it for any profit-making activity or commercial gain

If the publication is distributed under the terms of Article $25 \mathrm{fa}$ of the Dutch Copyright Act, indicated by the "Taverne" license above, 


\section{Diet and nonalcoholic fatty liver disease Ronald P. Mensink, Jogchum Plat and Patrick Schrauwen}

Department of Human Biology, Nutrition and Toxicology Research Institute Maastricht (NUTRIM), Maastricht University, Maastricht, The Netherlands

Correspondence to Ronald P. Mensink, PhD, Department of Human Biology, Nutrition and Toxicology Research Institute Maastricht (NUTRIM), Maastricht University, Universiteitssingel 50, 6229 ER Maastricht, P.O. Box 616

6200 MD Maastricht, The Netherlands

Tel: +31 43388 1742; fax: +31 433670976 ; e-mail: R.Mensink@HB.UNIMAAS.NL

Current Opinion in Lipidology 2008, 19:25-29

\section{Purpose of review}

Nonalcoholic fatty liver disease is a common and serious form of chronic liver disease. It is characterized by lipid accumulation in the liver and is associated with all aspects and may even be an initiating factor - of the metabolic syndrome. The purpose of this review is to summarize recent findings from human studies on dietary effects on hepatic lipid accumulation.

\section{Recent findings}

Epidemiological studies did not give consistent results. From intervention studies there is evidence to support a role for weight loss. Some studies have also suggested that decreasing total fat intake and increasing the intake of fish oils may be beneficial in the treatment of nonalcoholic steatohepatitis.

\section{Summary}

Only a few studies have focused on dietary effects on hepatic lipid accumulation. So far, there is only evidence to support a role for weight loss. Decreasing total fat intake and increasing the intake of fish oils may also be beneficial, but these conclusions are based on a limited number of studies, which sometimes lacked a proper control group. Also, other nutrients have not been studied in detail. Therefore, there is an urgent need for evidence-based dietary guidelines to prevent or even to treat nonalcoholic fatty liver disease.

\section{Keywords}

dietary fat, dietary fatty acids, energy intake, nonalcoholic fatty liver disease

Curr Opin Lipidol 19:25-29

(C) 2008 Wolters Kluwer Health | Lippincott Williams \& Wilkins 0957-9672

\section{Introduction}

Nonalcoholic fatty liver disease (NAFLD) is a chronic liver disease that covers a wide variety of clinical conditions, ranging from simple steatosis (a fatty liver) without any signs of inflammation to severe inflammatory activity with significant fibrosis or even cirrhosis. This latter condition is called nonalcoholic steatohepatitis (NASH). Although no generally accepted definition exists, NAFLD can be defined as fat accumulation in the liver exceeding $5-10 \%$ by wet weight [1]. The prevalence of NAFLD is high and will increase in the very near future, which will put many people at risk of advanced liver diseases such as cirrhosis and hepatic cancer. In addition, patients with NAFLD have a higher prevalence of insulin resistance and cardiovascular disease $\left[2,3^{\bullet \bullet}, 4^{\bullet \bullet}\right]$. Also other characteristics of the metabolic syndrome - for example hyperlipidemia and hypertension - are more common in these patients $\left[5,6^{\bullet \bullet}\right]$. In fact, it has been suggested that a fatty liver is a predisposing factor for the development of the metabolic syndrome $\left[6^{\bullet \bullet}\right]$. This indicates that not only the total amount and distribution of body fat but also tissue storage is important in determining the health consequences of obesity $\left[4^{\bullet \bullet}\right]$.
What is especially worrying is that NAFLD is prevalent not only in adults but also in children. For the United States, for example, it has been estimated that the prevalence of NAFLD is $33 \%$ in adults, and $10 \%$ in children and adolescents [7]. The exact causes of NAFLD are still unknown, but it is clearly associated with an increased body mass index (BMI) [8]. Inherent to the definition, however, the cause of NAFLD is not alcohol related. It is important to note, however, that hepatic lipid accumulation can also be increased in subjects with a BMI under $25 \mathrm{~kg} / \mathrm{m}^{2}$ [8].

Owing to the health consequences of NAFLD, interest in this disease has increased over the last years. For a long time, many of the studies on NAFLD were performed in cellular and animal models, due to the inaccessibility of liver biopsies in humans. The introduction of noninvasive imaging technologies, such as magnetic resonance imaging and spectroscopy, and ultrasonography, has made it possible to determine liver fat content in human subjects in a noninvasive way and several reviews have recently been published $\left[5,6^{\bullet \bullet}, 9,10\right]$. In these reviews, however, the focus was in particular on diagnostics, prevalence and prognosis, metabolic 
aberrations, and drug therapy. Less attention has been paid to nutritional aspects. The aim of this review is now to summarize recent findings from human studies on the dietary effects on lipid liver accumulation and the severity of NAFLD. The focus will be on total energy intake and dietary macronutrient composition, which are well known determinants of the various components of the metabolic syndrome $\left[11^{\circ}\right]$. Only those studies were selected that measured NAFLD using liver biopsies or noninvasive methods. Although serum concentrations of alanine aminotransferase (ALT) and other liver enzymes correlate with hepatic lipid accumulation, their sensitivity and specificity to diagnose NAFLD is low $\left[6^{\bullet \bullet}\right]$.

\section{Epidemiological studies}

The practical difficulties to assess liver fat content in a large number of subjects have resulted in a limited number of epidemiological studies on diet as related to NAFLD. Only a few, relatively small, studies have been published (Table 1).

Musso et al. [12] compared daily food intake data of 25 patients with NASH with those of 25 controls. Total energy intake between the two groups was similar. Protein intake was, however, higher in the NASH group. Carbohydrate intake and total fat intake were similar, but patients with NASH consumed more

Table 1 Effects of dietary energy and macronutrient intakes on the presence or severity of nonalcoholic fatty liver disease: results from cross-sectional epidemiological studies

\begin{tabular}{|c|c|c|c|c|c|c|}
\hline \multirow{2}{*}{$\frac{\text { Study }}{\text { Musso [12] }}$} & \multirow{2}{*}{$\begin{array}{l}\text { Population } \\
25 \text { patients with NASH } \\
\text { versus } 25 \text { controls } \\
\text { matched for age, } \\
\text { sex and BMl }\end{array}$} & \multirow{2}{*}{$\begin{array}{l}\text { Diagnosis } \\
\text { Ultrasonography }\end{array}$} & \multirow{2}{*}{$\begin{array}{l}\begin{array}{c}\text { Assessment of } \\
\text { food intake }\end{array} \\
\begin{array}{c}\text { 7-day food } \\
\text { diet record }\end{array}\end{array}$} & \multicolumn{2}{|c|}{$\begin{array}{l}\text { Statistically significant } \\
\text { differences in dietary } \\
\text { energy and } \\
\text { macronutrient intakes }\end{array}$} & \multirow[t]{2}{*}{ Remarks } \\
\hline & & & & $\begin{array}{l}\text { Energy } \\
\text { Carbohydrate } \\
\text { Protein } \\
\text { Total fat } \\
\text { SAFA } \\
\text { MUFA } \\
\text { PUFA }\end{array}$ & $\begin{array}{l}20.2 \text { versus } 16.7 \mathrm{En} \% \\
13.7 \text { versus } 10.0 \mathrm{En} \% \\
3.5 \text { versus } 4.7 \mathrm{En} \%\end{array}$ & \\
\hline Solga [14] & $\begin{array}{l}70 \text { morbidly obese } \\
\text { patients }\end{array}$ & Liver biopsy & $\begin{array}{l}\text { 24-h food } \\
\text { recall }\end{array}$ & $\begin{array}{l}\text { Energy } \\
\text { Carbohydrate } \\
\text { Total fat } \\
\text { SAFA } \\
\text { MUFA } \\
\text { PUFA }\end{array}$ & & $\begin{array}{l}\text { Carbohydrate intake was } \\
\text { positively - and fat } \\
\text { negatively - related to } \\
\text { degree of inflammation }\end{array}$ \\
\hline Pietiläinen [13] & $\begin{array}{l}19 \text { monozygotic } \\
\text { twin pairs }\end{array}$ & $\begin{array}{l}\text { Proton } \\
\quad \text { spectroscopy }\end{array}$ & $\begin{array}{l}\text { 3-day food } \\
\text { diaries }\end{array}$ & $\begin{array}{l}\text { Protein } \\
\text { Carbohydrate } \\
\text { Total fat } \\
\text { SAFA } \\
\text { MUFA } \\
\text { PUFA } \\
\text { Alcohol }\end{array}$ & & $\begin{array}{l}\text { Fat and SAFA intakes were } \\
\text { positively correlated with } \\
\text { percentage liver fat }\end{array}$ \\
\hline Zelber-Sagi [15] & $\begin{array}{l}108 \text { patients with NAFLD } \\
\text { versus } 241 \text { controls }\end{array}$ & Ultrasound & $\begin{array}{l}\text { Semiquantitative } \\
\text { food frequency } \\
\text { questionnaire }\end{array}$ & $\begin{array}{l}\text { Energy } \\
\text { Protein } \\
\text { Carbohydrate } \\
\text { Total fat } \\
\text { SAFA } \\
\text { MUFA } \\
\text { PUFA }\end{array}$ & & $\begin{array}{l}\text { Macronutrient intakes were } \\
\text { comparable between } \\
\text { the two groups } \\
\text { Patients with NAFLD had } \\
\text { higher intakes of } \\
\text { carbohydrates from soft } \\
\text { drinks and protein from } \\
\text { meat }\end{array}$ \\
\hline Cortez-Pinto [16] & $\begin{array}{l}45 \text { patients with } \mathrm{NASH} \\
\text { versus } 856 \text { controls } \\
\text { matched for age, } \\
\text { sex and alcohol } \\
\text { consumption }\end{array}$ & Liver biopsy & $\begin{array}{l}\text { Semiquantitative } \\
\text { food frequency } \\
\text { questionnaire } \\
\text { over } 1 \text { year }\end{array}$ & $\begin{array}{l}\text { Energy } \\
\text { Protein } \\
\text { Carbohydrates } \\
\text { Total fat } \\
\text { SAFA } \\
\text { MUFA } \\
\text { n-6 PUFA } \\
\text { n-3 PUFA }\end{array}$ & $\begin{array}{l}99.8 \text { versus } 104.9 \mathrm{~g} \\
243.6 \text { versus } 261.5 \mathrm{~g} \\
79.7 \text { versus } 73.0 \mathrm{~g} \\
\\
37.9 \text { versus } 31.8 \mathrm{~g} \\
9.3 \text { versus } 8.3 \mathrm{~g}\end{array}$ & \\
\hline Toshimitsu [17] & $\begin{array}{l}28 \text { patients with NASH } \\
\text { versus } 18 \text { patients } \\
\text { with simple steatosis }\end{array}$ & Liver biopsy & $\begin{array}{l}\text { 3-day food } \\
\text { diet record }\end{array}$ & $\begin{array}{l}\text { Energy } \\
\text { Protein } \\
\text { Carbohydrate } \\
\text { Total fat } \\
\text { SAFA } \\
\text { MUFA } \\
\text { PUFA }\end{array}$ & & $\begin{array}{l}\text { No significant relationships } \\
\text { were found using logistic } \\
\text { regression analysis }\end{array}$ \\
\hline Capristo [18] & $\begin{array}{l}20 \text { male patients with } \\
\text { NASH versus } 20 \\
\text { age-matched controls }\end{array}$ & Not reported & $\begin{array}{l}\text { 7-day food } \\
\text { diary }\end{array}$ & Energy & 2210 versus $1880 \mathrm{kcal}$ & \\
\hline
\end{tabular}


saturated and less polyunsaturated fatty acids than controls.

In 19 monozygotic twins Pietiläinen et al. [13] reported a positive association between the amount of liver fat and the intake of total and saturated fat. Solga et al. [14], however, found no relationship between the habitual intakes of saturated, monounsaturated and polyunsaturated fatty acids with the degree of steatosis, inflammation and fibrosis in 70 morbidly obese patients. In addition, no association was found between these three parameters and total energy intake. Total carbohydrate intake was, however, positively related to the degree of inflammation, but not with steatosis or fibrosis. The opposite relationship was found for total fat intake.

These findings are supported to some extent by one of the largest epidemiological surveys carried out so far. In that study, Zelber-Sagi et al. $\left[1^{\circ}\right]$ examined the dietary habits of 108 patients diagnosed with NAFLD versus those of 241 subjects without NAFLD. Subjects were randomly selected from the national population registry. After adjusting for potential confounding variables such as age, sex, BMI and total energy intake, patients with NAFLD had higher intakes of carbohydrates from soft drinks and of protein from meats. The intake of protein from fish rich in n-3 long-chain polyunsaturated fatty acids tended to reduce the risk for NAFLD. It was not mentioned whether the n-3 long-chain polyunsaturated fatty acids were also related with NAFLD.

Cortez-Pinto et al. [16], however, reported that patients with NASH had lower intakes of protein, but higher intakes of total fat, and of monounsaturated and $n-6$ polyunsaturated fatty acids. Consumption of n-3 polyunsaturated fatty acids was comparable between the two groups. Results were adjusted for energy intake and BMI.

Lower intakes of protein by patients with NASH were also reported by Toshimitsu et al. [17]. In that study, the dietary habits of 28 patients with NASH were compared with those of 18 patients with simple steatosis. Consumption of carbohydrates was higher in those with NASH. Results, however, did depend on the age of the subjects and were for the NASH group not always different from those of randomly selected healthy Japanese subjects, which makes it difficult to explain the results. In addition, logistic regression analysis did not reveal any statistically significant association between nutrient intakes and NASH.

Finally, one study [18] with 20 male patients with NASH and 20 healthy male control subjects reported a significantly higher energy intake in the patients with NASH.

A few cross-sectional studies have addressed the relationships between energy and macronutrient intakes with
NAFLD or its severity. As shown in Table 1, results are conflicting and no uniform conclusions can be drawn. This can be due to a wide variety of factors such as the relatively small sample sizes of the study populations, differences in population and control groups, and inaccuracies in estimating dietary intakes. In addition, due to the cross-sectional nature, patients may have changed their dietary habits because of their disease. In general, cross-sectional studies do not allow conclusions to be drawn on cause-effect relationships. For this, properly controlled randomized intervention studies are needed.

\section{Intervention studies}

Several recent intervention studies have been carried out to examine the effects of dietary composition on NAFLD. In most of these studies, the focus was on weight loss through energy restriction or on the effects of total fat intake or fatty acid composition. Some studies, however, have also looked at the effects of vitamin $\mathrm{E}$ or energy restriction combined with physical activity.

\section{Weight loss}

As NAFLD is positively associated with BMI and other features of the metabolic syndrome, it is obvious that a weight loss programme may be a first approach for overweight and obese subjects to treat NAFLD. The number of trials on the relationship between dietinduced weight loss and NAFLD, however, is surprisingly limited. In fact, Clark [19] reviewed in 2006 the existing literature and identified only three trials that had included a control group. If anything, these studies did suggest some improvement in liver histology and a decrease in liver enzymes related to NAFLD. In only one of the studies, however, histological endpoints were used. Owing to these methodological constraints, it was concluded that there is as yet only little evidence to support a role for diet-induced weight loss in the treatment of NAFLD.

In a more recent study, Thomas et al. [20] showed in 10 patients that a reduction in total calorie intake of $500 \mathrm{kcal}$ and advice to increase physical activity for 6 months decreased intrahepatocellular lipids (IHCLs) by $40 \%$ as measured by magnetic resonance imaging. Owing to a large between-subject variation this change did not reach statistical significance. Weight loss amounted to $3.4 \mathrm{~kg}$ or $4 \%$ of body weight. Interestingly, changes in IHCLs correlated positively with those in body weight, and in intra-abdominal and abdominal subcutaneous adipose tissue. Comparable results were found in an earlier study of Tiikkainen $e t$ al. [21].

\section{Total dietary fat content}

Short-term postprandial effects on IHCLs were assessed by Szczepaniak et al. [8]. After an overnight 
fast, the IHCLs of eight subjects were measured by magnetic resonance spectroscopy. Subjects then consumed a high-fat meal providing $50 \mathrm{~g}$ of fat. Four hours after the meal, measurements were repeated. No changes were observed.

Westerbacka et al. [22] have studied the effects of the amount of fat in the diet on liver steatosis, as measured with magnetic resonance proton spectroscopy. For this, 10 normal, obese women received for 2 weeks a low-fat diet, in which $16 \%$ of total energy intake (En\%) was provided by fat, or a high-fat diet $(56 \mathrm{En} \%)$ in randomized order using a crossover design. On the low-fat diet, the intakes of saturated, monounsaturated, and polyunsaturated fatty acids were decreased. This makes it impossible to attribute the effects observed to one single class of fatty acids. Before the start of the experimental periods, liver fat content was on average $10 \%$ and decreased to $8 \%$ on the low-fat diet and increased to $13.5 \%$ on the high-fat diet. On the high-fat diet, fasting serum insulin concentrations were also increased, while no effects on plasma glucose concentrations were observed, suggesting the development of insulin resistance. Surprisingly, the expected effects of the huge changes in total fat and fatty acid intake on the serum lipid or lipoprotein profile were not observed.

\section{Fish oils}

As for total fat intake, the effects of individual fatty acids on improving NAFLD have hardly been studied. Good candidates are of course the highly unsaturated fish oils, which are thought to improve insulin sensitivity [23]. Capanni et al. [24] therefore fed for 1 year 42 patients with NAFLD $1 \mathrm{~g}$ of fish oil daily. Fourteen patients who were not willing to swallow the fish oil capsules were used as controls. Thus, it was a nonblinded, nonrandomized study. After the intervention period, no liver steatosis as measured by ultrasonography could be demonstrated in $24 \%$ of the patients in the fish oil group, whereas no changes were observed in the control group. Liver enzyme levels and serum triacylglycerol and glucose concentrations were also improved. Preliminary results of a study that has been published as an abstract only also suggest that a daily supplement of $2 \mathrm{~g}$ of fish oil for 6 months resulted in regression of steatosis as determined by ultrasonography [25].

\section{Vitamin E}

In an earlier open-label pilot study, it was suggested that a daily supplement of $100 \mathrm{mg} \alpha$-tocopherol three times a day for 1 year may have a beneficial effect on NAFLD in patients with NASH [26]. A later study [27] also examined the potential beneficial effects of vitamin E. In that study, 28 children with obesity-related hypertransaminasaemia and increased IHCLs were randomly assigned to receive placebo pills or pills filled with $\alpha$-tocopherol acetate. For the first 2 months, $400 \mathrm{mg} /$ day was given and for the next 3 months $100 \mathrm{mg} / \mathrm{day}$. In addition, all children were prescribed a balanced lowenergy diet and a moderate daily exercise programme. No differences between the treatment groups were found in IHCLs at ultrasonography [27].

\section{Multidisciplinary intervention programmes}

Huang et al. [28] studied the effects of a recommended diet combined with an increase in physical activity on the progression of NASH. Sixteen patients completed the 12-month study, of which 15 underwent repeated liver biopsies. Compared with patients with unchanged histologic scores, patients with improved scores had significantly greater reductions in body weight.

In a nonplacebo-controlled study, de Piano et al. [29] studied the effects of a multidisciplinary programme on the dietary and metabolic profiles of 43 nonobese adolescents, aged between 15 and 19 years. Thirteen participants had NAFLD as diagnosed by ultrasonography. Before and after a 12-week intervention programme blood samples were taken. The intervention programme consisted of an aerobic training programme and a dietary programme. After the intervention, the number of subjects with NAFLD had decreased. Unfortunately, no detailed information was given on the dietary intervention programme. In addition, it was mentioned that energy and cholesterol intake had decreased in the NAFLD group, but no between-group comparisons were made. In a pilot study with 10 subjects, Hollingsworth et al. [30] showed that a diet that provided less than $20 \mathrm{~g}$ daily of carbohydrate reduced hepatic fat content as measured with MRI within 10 days. All subjects also lost weight $(3 \mathrm{~kg})$, which did not however correlate with changes in hepatic fat loss.

\section{Summary}

The number of randomized intervention studies to examine relationships between NAFLD and dietary macronutrient composition is limited. There is evidence to support a role for weight loss. The role of decreasing total fat intake and increasing the intake of fish oils in the treatment of NAFLD is weaker.

\section{Conclusion}

NAFLD is a common and potentially serious form of chronic liver disease that occurs in patients who do not abuse alcohol. Therefore, there is an urgent need for evidence-based dietary guidelines to prevent or even to treat NAFLD. Surprisingly, only little is known about the effects of decreasing energy intake and dietary macronutrient composition on the development and treatment of NASH. The cross- sectional epidemiological studies did not give consistent results, which are in addition prone to bias. Many of the intervention studies were 
not randomized and conclusions were sometimes based on within-group comparisons instead of between-group comparisons. There is evidence, however, to support a role for weight loss. Some studies also suggested that decreasing total fat intake and increasing the intake of fish oils may be beneficial in the treatment of NAFLD. Clearly, however, more rigorously conducted, randomized controlled trials using realistic dietary intakes are needed in this area.

\section{References and recommended reading}

Papers of particular interest, published within the annual period of review, have been highlighted as:

- of special interest

-• of outstanding interest

Additional references related to this topic can also be found in the Current World Literature section in this issue (p. 88).

1 Neuschwander-Tetri BA, Caldwell SH. Nonalcoholic steatohepatitis: summary of an AASLD Single Topic Conference. Hepatology 2003; 37:1202-1219.

2 Park SH, Kim BI, Kim SH, et al. Body fat distribution and insulin resistance: beyond obesity in nonalcoholic fatty liver disease among overweight men. J Am Coll Nutr 2007; 26:321-326.

3 Targher G, Bertolini L, Padovani R, et al. Prevalence of nonalcoholic fatty liver

- disease and its association with cardiovascular disease among type 2 diabetic patients. Diabetes Care 2007; 30:1212-1218.

This study showed that NAFLD is extremely common in patients with type 2 diabetes and is associated with an increased cardiovascular risk.

4 Vega GL, Chandalia M, Szczepaniak LS, Grundy SM. Metabolic correlates of -• nonalcoholic fatty liver in women and men. Hepatology 2007; 46:716-722. This paper suggests that especially insulin resistance combined with obesity is related to NAFLD.

5 Marchesini G, Marzocchi R, Agostini F, Bugianesi E. Nonalcoholic fatty liver disease and the metabolic syndrome. Curr Opin Lipidol 2005; 16:421-427.

6 Kotronen A, Yki-Jarvinen H. Fatty liver. A novel component of the metabolic -• syndrome. Arterioscler Thromb Vasc Biol 2007; 9 Aug [Epub ahead of print].

This is a comprehensive review on the health and metabolic effects of NAFLD.

7 Angulo P. Obesity and nonalcoholic fatty liver disease. Nutr Rev 2007; 65:S57-S63.

8 Szczepaniak LS, Nurenberg P, Leonard D, et al. Magnetic resonance spectroscopy to measure hepatic triglyceride content: prevalence of hepatic steatosis in the general population. Am J Physiol Endocrinol Metab 2005; 288:E462E468.

9 Adams LA, Lindor KD. Nonalcoholic fatty liver disease. Ann Epidemiol 2007; 17:863-869.

10 Gaemers IC, Groen AK. New insights in the pathogenesis of nonalcoholic fatty liver disease. Curr Opin Lipidol 2006; 17:268-273.

11 Zivkovic AM, German JB, Sanyal AJ. Comparative review of diets for the

- metabolic syndrome: implications for nonalcoholic fatty liver disease. Am J Clin Nutr 2007; 86:285-300.

This is a review of the effects of diet and dietary components on the various aspects of the metabolic syndrome.
12 Musso G, Gambino R, De Michieli F, et al. Dietary habits and their relations to insulin resistance and postprandial lipemia in nonalcoholic steatohepatitis. Hepatology 2003; 37:367-372.

13 Pietiläinen $\mathrm{KH}$, Rissanen A, Kaprio J, et al. Acquired obesity is associated with increased liver fat, intra-abdominal fat, and insulin resistance in young adult monozygotic twins. Am J Physiol Endocrinol Metab 2005; 288:E768-E774.

14 Solga S, Alkhuraishe AR, Clark JM, et al. Dietary composition and nonalcoholic fatty liver disease. Dig Dis Sci 2004; 49:1578-1583.

15 Zelber-Sagi S, Nitzan-Kaluski D, Goldsmith R, et al. Long term nutritional

- intake and the risk for nonalcoholic fatty liver disease (NAFLD): A population based study. J Hepatol 2007; 14 Aug [Epub ahead of print].

A large-scale cross-sectional study suggested that patients with NAFLD have a higher intake of soft drinks and meat.

16 Cortez-Pinto $\mathrm{H}$, Jesus $\mathrm{L}$, Barros $\mathrm{H}$, et al. How different is the dietary pattern in nonalcoholic steatohepatitis patients? Clin Nutr 2006; 25:816-823.

17 Toshimitsu K, Matsuura B, Ohkubo I, et al. Dietary habits and nutrient intake in nonalcoholic steatohepatitis. Nutrition 2007; 23:46-52.

18 Capristo E, Miele L, Forgione A, et al. Nutritional aspects in patients with nonalcoholic steatohepatitis (NASH). Eur Rev Med Pharmacol Sci 2005. 9:265-268

19 Clark JM. Weight loss as a treatment for nonalcoholic fatty liver disease. J Clin Gastroenterol 2006; 40 (Supp. 1):S39-S43.

20 Thomas EL, Brynes AE, Hamilton G, et al. Effect of nutritional counselling on hepatic, muscle and adipose tissue fat content and distribution in nonalcoholic fatty liver disease. World J Gastroenterol 2006; 12:5813-5819.

21 Tiikkainen M, Bergholm R, Vehkavaara S, et al. Effects of identical weight loss on body composition and features of insulin resistance in obese women with high and low liver fat content. Diabetes 2003; 52:701-707.

22 Westerbacka J, Lammi K, Häkkinen A-M, et al. Dietary fat content modifies liver fat in overweight nondiabetic subjects. J Clin Endocrinol Metab 2005; 90:2804-2809.

23 Riccardi G, Giacco R, Rivellese AA. Dietary fat, insulin sensitivity and the metabolic syndrome. Clin Nutr 2004; 23:447-456.

24 Capanni M, Calella F, Biagini MR, et al. Prolonged n-3 polyunsaturated fatty acid supplementation ameliorates hepatic steatosis in patients with nonalcoholic fatty liver disease: a pilot study. Aliment Pharm Ther 2006; 23:1143-1151.

25 Spadaro L, Magliocco O, Spampinato D, et al. Omega-3 polyunsaturated fatty acids: a pilot trial in nonalcoholic fatty liver disease. J Hepatol 2006; 44:S264.

26 Hasegawa T, Yoneda M, Nakamura K, et al. Plasma transforming growth factorbeta1 level and efficacy of alpha-tocopherol in patients with nonalcoholic steatohepatitis: a pilot study. Aliment Pharmacol Ther 2001; 15:1667-1672.

27 Vajro $\mathrm{P}$, Mandato $\mathrm{C}$, Franzese A, et al. Vitamin $\mathrm{E}$ treatment in pediatric obesityrelated liver disease: a randomized study. J Pediatr Gastroenterol Nutr 2004; 38:48-55.

28 Huang MA, Greenson JK, Chao C, et al. One-year intense nutritional counseling results in histological improvement in patients with nonalcoholic steatohepatitis: a pilot study. Am J Gastroenterol 2005; 100:1072-1081.

29 de Piano A, Prado WL, Caranti DA, et al. Metabolic and nutritional profile of obese adolescents with nonalcoholic fatty liver disease. J Pediatr Gastr Nutr 2007; 44:446-452.

30 Hollingsworth KG, Abubacker MZ, Joubert I, et al. Low-carbohydrate diet induced reduction of hepatic lipid content observed with a rapid noninvasive MRI technique. Br J Radiol 2006; 79:712-715. 